Intermédialités : histoire et théorie des arts, des lettres et des techniques I Intermediality: History and Theory of the Arts, Literature and Technologies

Numéro 24-25, automne 2014, printemps 2015

projeter / projecting

Sous la direction de Larisa Dryansky et Érika Wicky

Direction : Marion Froger (directrice)

Éditeur : Revue intermédialités (Presses de l'Université de Montréal)

ISSN : 1920-3136 (numérique)

DOI : 10.7202/1034161ar

\title{
Article
}

\section{The Automatic Exhibition: Slide Shows and Electronics at the Swiss National Exhibition 1964}

\section{Olivier Lugon}

Université de Lausanne

\section{Abstract}

The advent of projection in exhibitions in the early 1960s brought with it a new form of automatized exhibition. Its rise was part of a larger phenomenon of automation and of rationalization of informational processes in Western society, with the rise of electronics. The Swiss National Exhibition in Lausanne in 1964 offers a good example of this: slide shows and multi-screen projections were used to promote administrative automation and to foster a new market of exhibition machinery.

\section{Résumé}

Au début des années 1960, l'avènement de la projection en exposition est indissociable d'une automatisation de l'exhibition des images; il participe ainsi d'un phénomène plus large d'automatisation et de rationalisation des processus informationnels dans la société occidentale avec l'essor de l'électronique. L'Exposition nationale suisse de Lausanne en 1964 en offre un bon exemple : diaporamas et projections multi-écrans y sont mis au service d'une célébration de l'automatisation administrative, ainsi que de la promotion d'un nouveau marché de la machinerie d'exposition.

Since 1896, Switzerland has been organizing national exhibitions on a regular basis, displaying products, machines, and works of art in order to promote the country's economic strengths as well as its cultural and political values. ${ }^{[*}$ The fifth of these exhibitions, Expo 64, took place in Lausanne in 1964. One of the main features of the show, highlighted by most commentators at the time, was the unprecedented presence of film and light projections. Screens and darkened rooms filled the spaces of the national exhibition and were perceived as one of the event's most important contributions to the long history of the exhibition medium. Since then, if studies have not failed to mention this aspect, they have tended to focus on just a few of the main attractions, and always the film-based ones, such as the short films by Henry Brandt, which were projected in La voie Suisse (The Swiss Way), [1] and the panoramic Disney Circarama, which was part of the Swiss Federal Railways section. In so doing, these studies have dismissed the fact that the kinds of projections presented were not limited to cinema but made use of a far wider range of techniques, including, in many of them, multi-screen projections of still images. An even larger number presented hybrid formulas, in which slides were mixed with films, or images were combined with mobile models, machines at work, and lighting effects. The hybrid nature of these presentations probably explains their absence from historiographical accounts of Expo 64 as well as from the history of the advent of the projected image in the context of exhibitions. Yet, this is also what makes them particularly interesting for a history that is not restricted to images per se but engages with techniques of image display, taking into account the industrial determinants and economic implications of these technologies.

2 The abundant literature generated over the last fifteen years on the topic of the exhibition of projected images has, more often than not, concentrated on the artistic appropriations of the luminous image, through the study of 
auteur creations, in particular those produced since the late 1960s. [2] Such a focus has led to a neglect of earlier forms of projection that were more popular and commercial, and produced in a more collective way. Although some studies have tried to bring to light an alternative history of projection, one that is longer and presents a greater diversity of actors, [3] they have nevertheless tended to subsume this history under that of the genealogy of "total cinema," thus providing only a partial account, which suppresses in particular the strong presence of the projected still image in the early 1960s.

During this period, the practice of slide shows was so vital that it produced a new word in French: diaporama. This neologism was coined in the early years of the decade in a milieu of French amateurs during the Festival international du montage photographique sonorisé in Vichy. [4] Although the term became common over the years, and is still used today to designate any presentation based on slides, this was not yet the case in 1964 . The word does not appear in any of the sources from the Lausanne Expo. [5] Moreover, coined as it was in the context of Vichy's festival of amateurs, it was originally meant to designate single, or at the most double, projections, and not the multi-screen forms that would come to dominate in exhibitions, along with the increasing involvement of professionals in the field. Indeed, to refer to the latter form, the Vichy amateurs spoke of "multivision" or, using a term that Abel Gance copyrighted in 1956, "polyvision." [6]

Nevertheless, two aspects of the term diaporama are significant with regard to the history of multi-screen projections in exhibitions. The first has to do with the structure of the word itself, which is a combination of the abbreviated word "diapo" from the French word for slide (diapositive) and the suffix "-rama." The latter resurrects a morpheme that was highly fashionable in the nineteenth century following the success of the panorama, the diorama, and other large-format pictorial attractions, before being banished from the lexicon of the avant-gardes, no doubt because of its illusionist connotations and its links to industrial forms of visual spectacle. Its resuscitation in the early 1960s to designate slide projections signalled a major displacement with regard to the older magic lantern show. In this way, projected still images were detached from the tradition of the stage, whether that of the theatre or that of the lecture hall-a tradition recalled by the English expression "slide show"- to be set within the genealogy of large pictorial spectacles. Hence, they were no longer associated with live performances bound to a strong human presence, be it that of the projectionist or that of the lecturer, but relocated within the history of the exhibition form of images displayed in succession without human intervention, as had been the case for centuries with painting.

This process was reinforced by the second defining element of the diaporama: the primacy of recorded sound. In fact, the term diaporama was initially proposed as a substitute for the too-burdensome montage photographique sonorisé (photographic montage with sound added). [7] With the diaporama, still images would also become sound pictures, and in light of the consequences brought on by the transition to talking pictures in cinema thirty years before, the feeling was that a new chapter in the history of photography was beginning. By displacing photography into the terrain of temporal and audio-visual media shared by film and television, it would be repositioned at the centre of future media communications.

6 The transition from silent, still image to image with recorded sound had many important implications. Most significant in the context of exhibition projections was the requirement of synchronization, which implied the automation of the display of images. The use of tape recorders played an essential role in this process. Far from merely playing sound, the tape recorder was simultaneously used as a machine to synchronize other machines: on one of its tracks, the magnetic tape transmitted impulses which, imperceptible to the human ear, were directed toward other machines to direct the succession of the images and coordinate the various apparatuses. It is on this aspect that I would like to focus: how, with the rise of slide projections in the early 1960s, images and automation met, and how, beyond being a mere technical determinant, automation was staged by projections in exhibitions, such as the one in Lausanne, and became a primordial element of their discourse. In so doing, I would like to reinscribe the infatuation with multi-screen projection that caught on at the time, from Lausanne's Expo 64 to the world's fairs of New York in 1964 and Montreal in 1967, within a larger phenomenon of automation and of rationalization of informational, administrative, and bureaucratic processes, which had an impact on Western society as a whole.

Of these fairs, it is Lausanne's Expo 64 that most clearly demonstrates the strong hybridity of early multi-screen projections in exhibitions. Although Expo 67 is the better-known example, it is also one in which film remained the dominant feature and, as such, the one that has been predominantly discussed in connection with topics related to the history of the film industry, from the National Film Board of Canada to IMAX technology. Moreover, the Lausanne exhibition provides a more complex view of the rise of electronics. Indeed, whereas the conception of the famous IBM Pavilion at the 1964 New York World's Fair was dominated by the discourse produced by the electronics industry itself, Lausanne's Expo demonstrated the impact of automation on a much broader scale, ranging from the photography industry and precision engineering to postal services. 


\section{Robot Projectors}

Regarding the slide projector itself, the turn of the 1960s saw the rise of a new generation of entirely automatic models, which featured mechanized loading by way of trays, predefined sequencing and timing, and the looped scrolling of images. In 1964, the magazine Camera welcomed these features euphorically as allowing for "the elimination of the human factor" in the display of projected images. [8] There were various kinds of such "robot apparatuses," as they were called in a manual at the time. [9] However, one in particular became emblematic of the new projectors in both form and name: the Carousel, launched by Kodak in 1961. Not only was its design based on the idea of the infinite loop, but it also guaranteed flawless automation by basing the loading of images on the inexorable force of gravity, as the slide fell in front of the light beam rather than being laterally transported in front of it, as had been the case until then (see Fig. 1). This system reveals the paradoxical nature of the slide: on the one hand an immaterial image, meant to produce a pure luminous presence, and on the other hand a solid object, whose actual weight was the necessary condition for the technical success of the projection-a heavy immaterial image of sorts, whether its frame was made of plastic or cardboard. In 1964, the Carousel had reached such a position of superiority on the market for projectors that many exhibitors in Lausanne planned to use it-until they realized that its beam was not strong enough for very large exhibition spaces. They then reverted to more professional models in the line of the Audax, a Swiss device developed in the 1940s by the Genevan Rodolphe Pechkranz in collaboration with the Ganz company in Zurich, which was the forerunner of the Kodak machine. [10]

Fig. 1

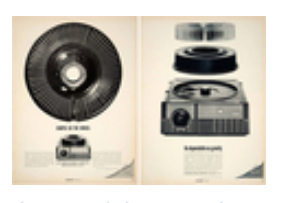

"Simple as the wheel" and "As dependable as gravity," advertising for the Kodak Carousel, Esquire, February and April 1963.

Image pleine grandeur

However, the prospect of the exhibition made it necessary to add new systems of inter-device synchronization to the machines' own automatic functions. These systems relied on magnetic tapes, as mentioned above, but also on other then-emerging electronic components, such as punched tapes and early computing devices. In Lausanne, this electronic equipment did not merely invade the exhibition space as an invisible instrument; certain sections of the exhibition staged the machinery as an attraction in its own right. This was the case, for example, with attractions in which computers playfully established the profiles of thousands of visitors based on a live poll, for instance with the famous Gulliver survey overseen by IBM, with the Arène du destin (Fate's Arena) part of the Exchanges of Goods and Services section, and in the centre of this same section, where an electronic machine conducted an "orchestra" of 156 electronically controlled office machines playing the symphony Les échanges by Rolf Liebermann. If automation was also the subject of controversy-the third question of the Gulliver survey asked, "What do you think about automation?"-[11]it was for the most part celebrated by the exhibition as an uncontested figure of progress, the source of new creative potentialities, and the necessary auxiliary to a flourishing Swiss economy confronted with the challenge of a labour shortage. The multi-screen slide shows, whose electronic nature was repeatedly noted in the publications produced for the national exhibition, appear to have been singled out as a particularly convincing channel for this discourse. The projections, with their sparkling bouquets of protean and colourful images, presented computerized coordination as a lively and joyful spectacle at a time when the objective was to accustom the Swiss population to the rule of intelligent machines, whether in the organization of labour or in the simplest everyday gestures.

To illustrate this, I have chosen four examples. In analyzing them, I have switched the focus from the artists who designed these shows, whose intentions are often poorly documented, to the discourses of those who commissioned them and of the companies responsible for their technical implementation. The role of these companies, I argue, largely exceeded that of providing mere technical backup.

\section{Projection in "Telegraphic Style"}

11 One attraction in particular deserves to be exhumed from the oblivion into which it has fallen over the last fifty years despite the fact that at the time Umberto Eco praised its "effects of great beauty," [12] and that it involved two major figures of twentieth-century Swiss visual arts, Max Bill and Alain Tanner. This was the section Le 
monde de l'image (Reality in Pictures). Conceived as a contribution by the Swiss Union of Photographers-at the time led by Gaston de Jongh-Le monde de l'image was situated in the vast half-sector Éduquer et créer (Education and Creation), designed by Max Bill, the goal of which was to bring together and coordinate the different domains of education, art, and the media. In this context, the challenge for professionals in the photography world was to promote their medium even though they themselves acknowledged that it was no longer dominant, or even relevant, in an exhibition setting, supplanted as it was by the moving image and projection. Nevertheless, they persisted in directing attention to photography, attempting to find ways to transform it into an animated spectacle that would, however, stay short of cinema. Hence, the choice of basing the entire attraction on the use of slides.

12 The visitors first encountered the slides in the form of a single, gigantic, translucent backlit colour image, which was meant to serve as a backdrop for the souvenir pictures that the visitors would take. The real show unfolded on the other side of this image: a six-minute-long program in a loop made up of a multi-projection on eight screens combining six sequences of slides and two films, coordinated by a stereophonic tape recorder. There are no remaining installation views or films documenting the exhibit, and the few surviving preliminary drawings and photographs of the model do not correspond to the final structure, which was less closed in than the quasipanoramic half-circle planned at the inception of the project (see Fig. 2). But the hesitation between the immersive model of the panorama and the more frontal and fragmented one provided by the kaleidoscope fed into the strong tensions that arose during the eminently conflictual elaboration of the show.

Fig. 2

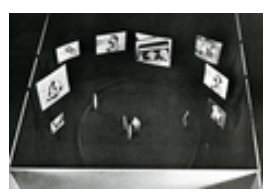

Model for the section Le monde de l'image, Paillard S. A., 1963.

Swiss Federal Archives, Berne

Image pleine grandeur

Indeed, in the preparatory phase two competing proposals emerged whose confrontation escalated into a near rupture at the end of 1962. On the one hand, there was the project headed by Ernst Scheidegger, the important graphic designer, photographer, filmmaker, and editor from Zurich, who in Lausanne worked as Max Bill's right hand and was the acting head graphic designer of the half-sector Éduquer et créer. On the other hand, there was the program conceived by Alain Tanner, then a young Genevan filmmaker who was not yet well known as a film director but on his way to making a name for himself in the domain of multi-projection. He had directed the triptych film L'école (The School) for the Swiss pavilion of the architects Georges Brera and Paul Waltenspühl at the Milan Triennial in 1960, and his name had circulated for several projects at Expo 64. [13] Although these activities are downplayed in his biography today, at the time he seemed genuinely interested in the new possibilities offered by both the succession and the juxtaposition of images, or, as he put it, by the conjunction of a "vertical" and "horizontal" editing of sequences. [14]

14 Fifty years later, the differences between the two competing projects seem quite tenuous. However, they touch upon fundamental oppositions with regard to the ways of delineating the specificities of the photographic medium in a field transformed by the rise of projection and animation, and thereby with regard to the agents authorized, or not, to intervene in its exhibition. More specifically, the escalation of the conflict between the team of the Zurich-based Scheidegger and the team around Tanner, which originated from the French-speaking part of Switzerland, had much to do with the major investment of an agent outside of the photographic field understood in the strictest sense of the term. This was the Paillard company, which was well known at the time for its amateur film camera, the Bolex. [15] Beyond this, the firm relied on a long tradition of making automatic machines that went back to music boxes in the nineteenth century, which shows the extent to which the history of multiprojection, and the emergence of "expanded cinema," is linked to a technical and industrial tradition, in this case crossing paths with a Swiss history of clock-making and precision engineering, which was also involved at the time in the development of the techniques of cinéma vérité. [16]

For Le monde de l'image, it was in fact Paillard, and not Bill, Tanner, or the Swiss Union of Photographers, that was behind a project for a multi-screen show combining still images, cinema, and sound. It was also Paillard that introduced Tanner into the game, primarily through the firm's representative at Expo 64, Jean de Senarclens, head of advertising and then assistant director of the company's film division. Beyond Le monde de l'image, Paillard got involved in the national exhibition at a very early stage and in many ways, and eventually received commissions for more than twenty audio-visual installations. For Le monde de l'image, the company managed to convince organizers to integrate the theme of non-professional cinema within the presentation of photography, and, more generally, to place the emphasis on amateur practices and their affective dimension. From Paillard's and Tanner's perspective, this aspect was to be transmitted by an exhibition with a strong emotional component, 
relying on the immersive use of multiple screens, and the primacy of a unified "ambience," which was to be created primarily by film.

6 Scheidegger and Bill, on the other hand, sought to present photography primarily as an instrument for information and knowledge. They envisaged multi-projection as a mosaic of clearly separate elements, an explicitly discontinuous structure in which images would follow one another and be juxtaposed by the use of a "telegraphic style," as Scheidegger put it.[17] They rejected the primacy of both "ambience"-_Too much ambience," protested Bill[18]—and film. This divergence of opinion—one favouring a kind of cinema with still images; the other, an openly additive slide show-slowly widened, finally crystallizing into a set of binary oppositions of a somewhat caricatural nature: "emotion" versus "abstraction," "human spectacle" versus "coolness," the "conventional" versus the "experimental," the "Latin" versus the "Nordic" approach. Such are the terms gathered from the reports and the intense correspondence exchanged after a difficult internal presentation session in Lausanne in November 1962. [19] The aim of the session was to decide between the projects on the basis of two trial excerpts projected on several screens. The outcome was in favour of the Tanner-Paillard option. Scheidegger was in fact asked to cooperate with Tanner, but although he was initially ready to oblige, he finally gave up. Bill, who was supposed to be the head architect of the section, was purely and simply excluded from meetings for several months.

\section{The Panorama and the Mosaic}

7 The tension between two models of multi-screen projection, unitary or additive, fluid or discontinuous, went beyond this specific conflict, and was present in numerous projections at Expo 64, even though it was rarely discussed so overtly. Everywhere, oscillations between immersion and fragmentation abounded, and often they became the very basis of the show, the beating heart of its specific power of attraction, which was gladly associated with the new potentialities of electronics.

Fig. 3

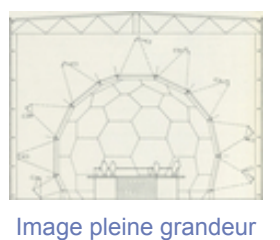

Cut on the projection structure of the Polyvision, information sheet Vacances en Suisse: Le tour de Suisse en 4000 images, Lausanne, 1964.

18 This was notably the case for Polyvision, produced by the Swiss National Agency for Tourism, whose name once again appropriated the neologism coined by Abel Gance, as if in the early 1960s the modern gaze was necessarily conceived according to an additive model. Developed by the architect Viktor Würgler, the artist and publisher René Creux, and the firm Ganz \& Co., which saw to the technical aspects, the program was titled Le tour de Suisse en 4000 images (Touring Switzerland in 4,000 Images). The structure, based on a hemispheric dome, extended the immersive tradition of the horizontal panorama in every direction, with the important difference that the panorama in this case was made of about sixty clearly separate elements, with hexagonal screens whose edges remained visible, and each screen lit by its own projector (see Fig. 3). The show constantly alternated between encompassing and mosaic views, as if in the time of computation there were no longer a structural distinction between the panorama and the kaleidoscope, as if any image could be transformed into an accumulation of smaller units, and vice-versa, at any moment-as if, in other words, the panorama was becoming a mere sub-category of the mosaic (see Figs. 4 and 5). The immersive illusion was explicitly turned into the product of a synchronization of devices, managed from an electronic control panel, a technical feature repeatedly highlighted in the promotional publications. The panoramic experience in this case was no longer equated with total absorption in an illusory spectacle but became, on the contrary, a means of enhancing awareness of the spectacle's technical conditions and of the powers of electronic coordination.

Fig. 4

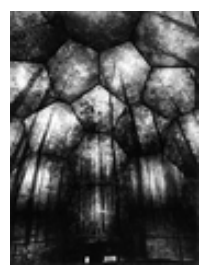

View of the Polyvision, conception by René Creux, architecture by Victor Würgler, technical conception Ganz \& Co.

Archives of modern construction, EPFL, Lausanne 
Fig. 5

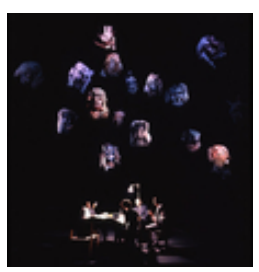

View of the Polyvision during the preparation.

Archives of modern construction, EPFL, Lausanne

Image pleine grandeur

\section{The New Exhibition Market}

9 To return to Paillard, the encounter between the luminous image and electronic coordination constituted an important industrial stake for the firm at the time, and Expo 64 was intended to act as a catalyst in the conquest of new markets. For decades, the company had in fact been as active in the production of cameras and film projectors as in the manufacture of typewriters. In the early 1960s, the office equipment section was strengthened thanks to a partnership with a Zurich-based calculator manufacturer, Precisa, and the launch of the first accounting devices, while the firm also introduced automated administration into the management of its own production and staff. From then on, as proclaimed in the title of the company newsletter (see Fig. 6), Paillard became a group whose particularity was to be situated at the crossroads of the audio-visual-cameras, projectors, but also audio devices with the absorption of Thorens-and office automation. As such, it was particularly well prepared to conquer the new and highly promising market of exhibition projections, which relied precisely on the juncture of these two areas of expertise. New synchronization machines, such as the Interlock system and the Paillard-Bolex programmer, were developed specifically for exhibitions. Expo 64 offered a unique platform for promoting new machines and securing new orders for fair stands, showrooms, and shops. Capitalizing on the experience gained from the event, Paillard published, very soon after, a brochure titled Un spectacle cinématographique nouveau pour les expositions, la publicité, la vente, [20] in which exhibitions were cast on a par with cinema as a truly technical medium that required the expertise of professionals from the domain of audio-visual machinery.

Fig. 6

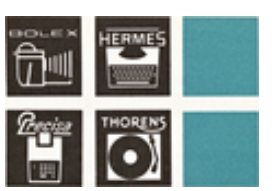

Header of Bulletin d'information Paillard, January 1964.

Cantonal archives of Vaud

Image pleine grandeur

20 Although this market never really took off, it seemed quite promising at the time for a large number of firms, among them Philips, which was also quite prominent at Expo 64. Philips produced the Globovision show (see Figs. 7 and 8) featured in the section Swiss Undertakings in the World. This was a multi-screen projection of great complexity, as it required the coordination of more than 450 devices (slide projectors, colour spotlights, amplifiers), 5,000 images, and 10,000 information signals, as well as several layered screens that slid out and appeared in succession as the program unfolded. [21] Philips sought in this way to capitalize on the success of the famous Poème électronique designed by Le Corbusier and Edgar Varèse for its pavilion at the Brussels World's Fair in 1958, and to establish a market for exhibition machinery for indoor and outdoor use, with the rise of sound-and-light shows. This market was quite peculiar: every project, regardless of its client and of the specificities of the product to be sold, was also meant to promote the very exhibition technique that it made use of. Philips in fact had wanted to call its show at Expo 64 not Globovision-a title that referred to the content of the show-but Temis 64 (Temps, Espace, Mémoire, Image, Son) in reference to the exhibition technique developed by the firm, which was the true product that it intended to showcase. In this regard, the early 1960s can be understood as an important turning point in the history of world's fairs and national exhibitions. The goal was no longer so much to present machines and techniques temporarily displaced into the foreign space of the exhibition, but to exhibit the very cogs of the display, elevated in their own right to the level of industrial marvels and objects to be sold, leading in this way to a sort of exhibition of the exhibition. [22] 
Drawing of the Globovision, section of Swiss Undertakings in the World.

Swiss National Museum, Zürich

Image pleine grandeur

Fig. 8

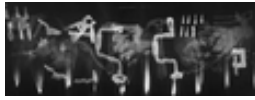

View of the Globovision projection, section of Swiss Undertakings in the World.

Archives of modern construction, EPFL

Image pleine grandeur

\section{Extension of the Carousel}

In Lausanne, one final presentation pushed even further this transformation of the exhibition into a vast automated machine. This was Rotorama, produced by the PTT, the Swiss Postal Telegraph and Telephone Agency (see Fig. 9). Now forgotten, the show attracted large crowds. [23] Much more than a projection room, it offered a full mechanical show, in which the projection of slides and films was coordinated with televised colour transmissions, animated models, mobile graphs, clocks, and machines at work. One of the essential consequences of the automated exhibition was here pushed to the limits: since every image was now inserted into a circuit of invisible signals directed solely to other devices, any iconic element could be coordinated with any other extra-iconic object or mechanical process. A commentator jokingly explained, for example, how publicity's instrument of persuasion-projection-could now be coupled with an instrument ensuring its efficiency-for instance, a distributor of contracts and pens. [24]

Fig. 9

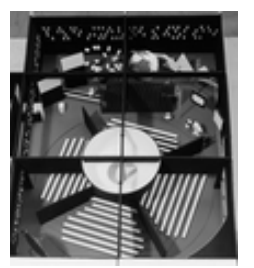

Model of the Rotorama.

Museum for Communication, Berne

Image pleine grandeur

22 This extended synchronization, involving a variety of mechanical and human processes, was at the heart of Rotorama, whose purpose was to celebrate the automation of the Swiss postal services using the very techniques that ensured its smooth operation. As expressed by Albert Morant, the general secretary of the state-owned company, "It is obvious that what is specific to the PTT, that is, transmission of image and sound, mechanization and automation, has to be put to use in the display technique itself." [25]

23 The company, regularly cited as an example of pioneering measures taken with regard to the automation of administration in Switzerland following its introduction of the computer in 1957,[26] was in the process of extending the automation of its services far beyond solely accounting operations, and Lausanne was at the heart of this development. Indeed, a new sorting office was under construction next to the city's main station. The new facility was supposedly the most modern one in Europe, [27] and it was designed to house one of the first automatic mail sorters, capable of deciphering addresses and routing envelopes correctly without any human intervention. However, its operation depended on an element that bore directly upon the daily life of Swiss citizens: the introduction of the zip code, an arbitrary number that they were now obliged to add to the address, with the implication that every letter was henceforth addressed both to a human being and to a machine. The announcement of this new rule elicited critical reactions from the press, which viewed it as a constraint for the user. The PTT intended to use Expo 64 to reply to this criticism and assure the Swiss population of the benefits of this imminent change. [28]

Fig. 10

Presentation of the automatic sorter of the new center of postal sorting of Lausanne, then in construction, in the Rotorama of the PTT, Sector of Communications and of Transports. 


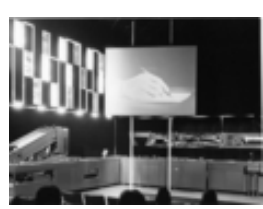

Image pleine grandeur

24 With this purpose in mind, the postal services decided to put the new automatic mail sorter to work in the middle of the slide projections, Cinemascope films, and television screens of Rotorama, turning it into the true star of the show (see Fig. 10). As they waited to gain entrance to the show, visitors were invited to mail free postcards that were at their disposal; upon entering the show, they discovered that the sorter was fed these same postcards. Machines at work, visual information, educational projections, and spectators-everything was thereafter coupled, with no distinction between a spectacle on and of automation. Moreover, as if the on-stage presence of this "cabaret mécanique" [29] were not enough, Rotorama invited visitors to become an integral part of the immense machine, which gave its name to the show (see Fig. 11): a rotating room composed of 600 seats, divided into four segments, that spun the public automatically to face four successive scenes, without any possibility of escaping the loop for the twenty minutes that the program lasted (see Fig. 12). [30]

Fig. 11

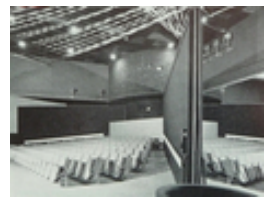

View of the space for spectators in the Rotorama (Bild und Ton, no 71, September 1964)

Historical PTT Archives, Köniz

Image pleine grandeur

Fig. 12

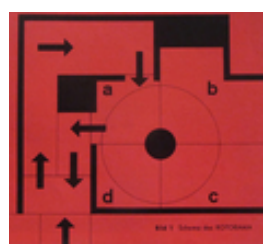

Scheme of the Rotorama (Bild und Ton, no 71, September 1964)

Historical PTT Archives, Köniz

Image pleine grandeur

5 It is worth noting that the heads of the postal services referred to this room as the "carousel." Nothing indicates that an allusion to Kodak's Carousel was effectively intended. However, the principle behind the show, whereby spectators found themselves turning at the same time as the images, and were synchronized to the unstoppable march of the projections and demonstration devices, illustrates the impact of the arrival of "robot apparatuses" on the history of the exhibition form. In fact, one of the arguments most often put forward at the time to convince exhibitors of the advantages of the multi-screen projection was a purely industrial one: by multiplying the succession of images appearing on a single portion of a wall's surface, and then by increasing the efficiency of the system by adding screens onto that same wall, multi-screen projections increased the profitability of exhibitions in an unprecedented way. Added to this was the benefit of cutting down on personnel costs thanks to automation.

26 Simply put, the example of Expo 64 makes it possible to nuance somewhat the recent historiography of exhibition projections, which has been dominated by the primacy of experimentations originating from the arts and from the counterculture of the late 1960s. Certainly, during those years, multi-screen projection could well be understood, in the wake of Marshall McLuhan, as having an affinity with the freeing of the mind, or even as a visualization of the human brain in electronic times, as demonstrated by the pavilion that Charles and Ray Eames designed for IBM in that same summer of 1964 in New York, or by Stan VanDerBeek's Movie-Drome, built the following year. Multi-screen projection has also been conceived in the context of psychedelic light-shows as a means to submit the technical image to the regime of improvisation, unbridled creativity, and the happening, all this in a mood of jubilation. But it is also useful to recall the other side of this history, and to point out to what extent this same type of projection, as gushing, multi-coloured, and protean as it may seem, was also aimed at the industrial rationalization of inter-human communication, and geared to a discourse of economic profitability. It was used not only to give a seductive image of the new processes of automated work, but also to make exhibition itself an integral part of the new regime of industrial productivity in the era of electronics. 
Olivier Lugon is an art historian and a professor at the Université de Lausanne. His research focuses on the history of photography, exhibition design, and slide projection in the twentieth century. He currently directs the Swiss National Science Foundation's research projects "Photography and Exhibition in Switzerland, 1920-1970" and "Encapsulating World Culture: The Rise and the Imaginary of Microfilm (1920s to 1950s)." Among his latest publications are Between Still and Moving Images (co-edited with Laurent Guido, 2012), Exposition et médias: photographie, cinéma, télévision (2012), Le Pont transbordeur de Marseille. Moholy-Nagy (with François Bon and Philippe Simay, 2013) and Revisiter l'Expo 64: acteurs, discours, controverses (co-edited with François Vallotton, 2014).

\section{Notes}

[^] This essay was first published in French, under the title "L'exposition automatique: diaporama et électronique à l'Expo 64," in Olivier Lugon and François Vallotton (eds.), Revisiter l'Expo 64: acteurs, discours, controverses, Lausanne, Presses polytechniques et universitaires romandes, 2014, p. 366-383.

[1] The titles of the sectors and sections provided in parentheses are those used in the trilingual version of the official exhibition book. See Alberto Camenzind (ed.), Construire une exposition/Eine Ausstellung bauen/Building an Exhibition, Lausanne, Marguerat, 1965.

[2] See in particular, Chrissie lles (ed.), Into the Light: The Projected Image in American Art 1964-1977, New York, Whitney Museum, 2001; Matthias Michalka (ed.), X-Screen: Filmische Installationen und Aktionen der Sechzigerund Siebzigerjahre, Vienna, Museum Moderner Kunst Stiftung Ludwig Wien/Cologne, König, 2003; Darsie Alexander (ed.), Slide Show: Projected Images in Contemporary Art, London, Tate Publishing, 2005; Anette Hüsch, Joachim Jäger, and Gabriele Knapstein (eds.), Beyond Cinema: The Art of Projection, Berlin, Hamburger Bahnhof/Ostfildern, Hatje Cantz, 2006; Philippe-Alain Michaud (ed.), Le mouvement des images, Paris, Centre Pompidou, 2006; Stan Douglas and Christopher Eamon (eds.), Art of Projection, Ostfildern, Hatje Cantz, 2009.

[3] See, in particular, Emmanuelle Michaux, Du panorama pictural au cinéma circulaire: origines et histoire d'un autre cinéma, 1785-1998, Paris, L'Harmattan, 1999; Valérie Peseux, La projection grand spectacle: du Cinérama à l'Omnimax, Paris, Dujarric, 2004.

[4] It is what the protagonists themselves state in their later publications, while remaining very elusive on the dates. See Jean Prissette, Le diaporama: des conseils et des trucages photographiques, Paris, Publications PhotoRevue, 1968; Claude Madier, Projections sonorisées et diaporamas, Paris, Montel, 1968; Claude Madier, Diaporamas et montages audio-visuels, Paris, Montel, 1975. It is worth noting that the first book by Claude Madier and Jean Bénézet on the topic in 1961, La Photo-projection et le montage photographique sonorisé (Paris, Montel), never makes use of the term "diaporama."

[5] In 1968, in his manual on the subject, Jean Prissette still takes the trouble to justify the use of a "barbarian" word. Prissette, 1968, p. 163.

[6] See Jean-Jacques Meusy, "La polyvision, espoir oublié d'un cinéma nouveau", 1895, no 31, October 2000, p. 153.

[7] Madier, 1975, p. 8.

[8] Andrew Matheson, "Fortschritt in der Diaprojektion", Camera, vol. 43, no 5, May 1964, p. 25.

[9] Prissette, 1968, p. 10.

[10] See, in particular, Thomas Ganz, Die Welt im Kasten: Von der Camera Obscura zur Audiovision, Zürich, Verlag Neue Zürcher Zeitung, 1994, as well as the website http://diaprojection.unblog.fr/ (accessed on August 26, 2015).

[11] The theme of automation was also present in the Industry and Handicrafts sector. See Claire-Lise Debluë, "Nous ne pouvons pas créer l'exposition sans les exposants': la controverse autour du projet Lucius Burckhardt pour le secteur de l'Industrie et de l'artisanat", in Lugon and Vallotton, 2014, p. 86-105.

[12] Umberto Eco, "Riposta a Harry Lime," Edilizia moderna, no 84, 1964, German translation in Georg Kohler and Stanislaus von Moos (eds.), Expo-Syndrom?: Materialien zur Landesausstellung 1883-2002, Zürich, VDF Hochschulverlag, 2002, p. 145.

[13] Besides Le monde de l'image, his name was also put forth to produce the Polyvision show, a responsibility ultimately entrusted to René Creux. See the letter by Jean-Jacques Demartines, head of the L'art de vivre sector, to Werner Kämpfen, director of the Swiss National Agency for Tourism, November 19, 1962 (Swiss Federal Archives, Berne, hereafter SFA).

[14] See Messrs. Tanner-Chenevière, "Projet: Groupe 'Photographie et Cinéma Substandard,' Exposition Nationale 1964," n. d. [September 1962] (SFA); Pierre Lugan, "Un film suisse à Milan," Gazette de Lausanne, July 16, 
1960, p. 9.

[15] See Roland Cosandey and Thomas Perret, Paillard, Bolex, Boolsky, Yverdon, Éditions de la Thièle, 2013.

[16] See Séverine Graff, Le cinéma-vérité. Films et controverses, Rennes, Presses universitaires de Rennes, 2014. On the importance of a history of synchronization techniques to the history of cinema and arts in general, see the issue "Synchroniser/Synchronizing" of Intermédialités, Philippe Despoix and Nicolas Donin (eds.), no 19, Spring 2012, www.erudit.org/revue/im/2012/v/n19/.

[17] Ernst Scheidegger, "Provisorischer Vorschlag Scheidegger zur Gestaltung der Projektionen im vorgeschlagenen verdunkelten Raum der Abteilung Fotografie," n. d. [September 1962] (SFA).

[18] Heinrich Schellenberg, session protocol of November 15, 1962, Palais de Beaulieu, Lausanne, November 21, 1962 (SFA). In his criticism, Bill moves Tanner's project closer to that of Disney's Circarama.

[19] All of these debates are documented in the Swiss Federal Archives.

[20] Un Spectacle cinématographique nouveau pour les expositions, la publicité, la vente, Yverdon, Bolex Paillard, [1964] (Cantonal Archives of Vaud).

[21] See, in particular, François Rochat, "Le cinéma à l'Exposition," Gazette littéraire, supplement of the Gazette de Lausanne, August 22-23, 1964, p. 9, 15, and "Entwurf des Textes für ein Plakat, das (deutsch und französisch) im Warteraum neben dem Eingang zur Globovision anzubringen wäre," June 20, 1964 (SFA). On the Globovision, see Jonathan Rudaz, "Globovision, un spectacle en 'technique d'ambiance' (Exposition nationale suisse Lausanne 1964)," Master's thesis, University of Lausanne, 2008.

[22] The self-reflexive and self-promotional nature of these apparatuses was noticed at the time: "It seems that the Polyvision, the Globovision, the Rotorama, and the Circarama are presented at the Expo as new, interesting, and stunning projection processes. Producers and filmmakers give the impression of having created their works with the primary goal to demonstrate the applicability of these new techniques". Hans Hartig, "Merveilles et techniques du cinéma," Feuille d'avis de Lausanne, October 9, 1964, p. 15.

[23] Fifteen days before the end of the Expo, with a million spectators to date, the Rotorama was said to be the thirdmost-visited projection show, after the film of the Army and the Circarama. "Exposition nationale: quelques grands succès," Feuille d'avis du Valais, October 14, 1964, p. 11.

[24] Peter Franke, "De nouveaux moyens d'information et de documentation," Revue suisse de photographie, vol. 29, no 16 , August 26, 1964, p. 450.

[25] Albert Morant, Generalsekretär der PTT, "Die PTT-Betriebe an der Schweizerischen Landesausstellung 1964," Revue des PTT, vol. 14, no 11, November 1963, p. 268.

[26] The information sheet of the PTT itself presents the state-owned company as "the first public agency in Switzerland to go from mechanization to automation of its accounting operations."

[27] See "Demain: le centre postal le plus moderne d'Europe," Revue des PTT, vol. 14, no 11, November 1963, p. 279.

[28] The importance of Lausanne in the process of automated postal distribution in Switzerland is still evident today, as the city was assigned the first zip-code number, 1000.

[29] Uz Oettinger, "Zerschnittene Lokomotive und amusante PTT an der Expo," Basler Nachrichten, August 1-2, 1964 (Historical PTT Archives, Köniz.)

[30] The idea would be taken up again in the Canadian pavilion at the Montreal World's Fair in 1967, but applied only to cinema.

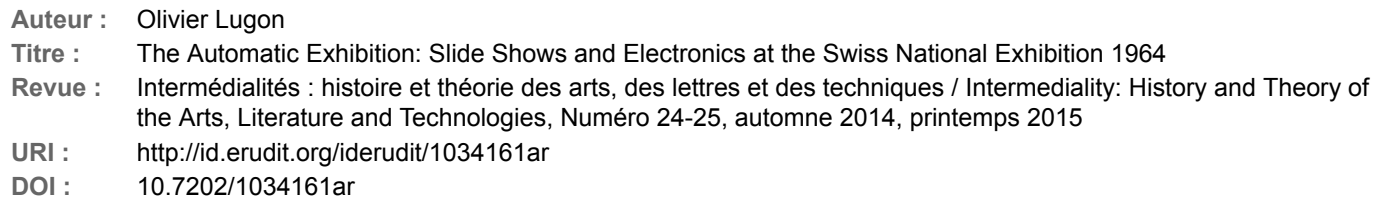

Tous droits réservés @ Revue Intermédialités, 2014 